\title{
Eficácia de fungicidas associados a inseticidas sobre o crestamento gomoso do caule e produtividade do meloeiro
}

\author{
Carlos Henrique Cardon; Gil Rodrigues dos Santos²; Paulo Henrique Tschoeke 3 , Solange Aparecida Ságio ${ }^{4}$; Mateus \\ Sunti Dalcin ${ }^{5}$; Raimundo Wagner de Souza Aguiar ${ }^{2}$
}

${ }^{1}$ Graduando em Agronomia, UFT - Gurupi, TO; ${ }^{2}$ Programa de Pós-Graduação em Produção Vegetal, UFT - Gurupi, TO; ${ }^{3}$ Aluno de doutorado em Produção Vegetal, UFT - Gurupi; ${ }^{4}$ Aluna de Pós Doutorado - UFT - Gurupi, TO; ${ }^{5}$ Aluno de mestrado em Produção Vegetal - UFT - Gurupi, Autor para correspondência: Gil Rodrigues dos Santos - (gilrsan@uft.edu.br)

Data de chegada: 29/07/2014. Aceito para publicação em: 26/08/2015.

$10.1590 / 0100-5405 / 2019$

\section{RESUMO}

Cardon, C.H.; Santos, G.R.; Tschoeke, P.H.; Ságio, S.A.; Dalcin, M.S.; Aguiar, R.W.S. Eficácia de fungicidas associados a inseticidas sobre o crestamento gomoso do caule e produtividade do meloeiro. Summa Phytopathologica, v.42, n.1, p.79-84, 2016.

Uma das mais importantes doenças que atacam o melão (Cucumis melo L.), é o Crestamento Gomoso do Caule, causada pelo fungo Didymella bryoniae que é altamente agressivo em condições de temperatura e umidade elevadas. Desta forma, o presente trabalho teve como objetivo avaliar a eficácia de fungicidas associados a inseticidas no controle do crestamento gomoso do caule do meloeiro em condições de campo naturalmente infestado. $\mathrm{O}$ trabalho foi realizado em dois ensaios, sendo que no ensaio I, foi utilizada a cultivar Eldorado 300 , com os tratamentos de inseticidas seletivos e não seletivos em mistura com fungicidas. Para o ensaio II, foi utilizado o híbrido Hibrix, com parte dos mesmos tratamentos do ensaio I. De acordo com os resultados, os tratamentos sem fungicida e as misturas de fungicida, inseticida seletivo e não seletivo com o uso de monitoramento de pragas e doenças, apresentaram níveis elevados de incidência do crestamento gomoso do caule do meloeiro e valores inferiores de produtividade de frutos. Ao contrario foi observado para os tratamentos com fungicida ou a mistura de fungicida com inseticida, mostraram maior eficiência no controle da doença, resultando em maiores índices produtivos.

Palavras-chave: Cucumis melo L.; Didymella bryoniae; Manejo integrado de doenças.

\section{ABSTRACT}

Cardon, C.H.; Santos, G.R.; Tschoeke, P.H.; Ságio, S.A.; Dalcin, M.S.; Aguiar, R.W.S. Efficacy of fungicides associated with insecticides on gummy stem blight and yield in melon plants Summa Phytopathologica, v.42, n.1, p.79-84, 2016.

One of the most important diseases that attack melon (Cucumis melo L.) is gummy stem blight, caused by the fungus Didymella bryoniae, which is highly aggressive under conditions of high temperature and humidity. Thus, the present study aimed to evaluate the efficacy of fungicides associated with insecticides in the control of gummy stem blight in melon plants under naturally infested field conditions. The experiment was conducted as two assays; in assay I, the cultivar Eldorado 300 was used with the treatments of selective and non-selective insecticides mixed with fungicides. For assay II, the hybrid Hibrix was used with part of the same treatments used in assay I. According to the results, the treatments without fungicide and the mixtures of fungicide and selective and non-selective insecticides, with the use of pest and disease monitoring, showed high levels of gummy stem blight incidence and lower values of fruit yield in melon plants. On the other hand, treatments with fungicide or the mixture of fungicide with insecticide showed greater efficiency in controlling the disease, which resulted in higher fruit yield.

Keywords: Cucumis melo L.; Didymella bryoniae; integrated disease management.

O cultivo de melão (Cucumis melo L.) no Brasil tem uma importância econômica crescente e atualmente, vem se destacando por ser uma das frutas frescas mais exportadas pelo país (4). No Estado do Tocantins, que apresenta estação seca definida, onde ocorre temperatura, umidade relativa do ar e radiação solar favoráveis, a cultura está se expandindo gradualmente a partir dos campos cultivados por pequenos agricultores (8). Apesar das condições ambientais e edáficas adequadas, a falta de cultivares com resistência e de manejo da cultura para o controle das doenças mais importantes dificulta a expansão do cultivo de melão no Tocantins.

Entre as doenças o crestamento gomoso do caule causado pelo fungo Didymella bryoniae, (Fuckel) Rehm 1881, é uma das mais agressivas do meloeiro, podendo causar danos na qualidade dos frutos (11) e perdas na produção de até $100 \%$ (19). Na cultura da melancia mesmo em épocas desfavoráveis à ocorrência da doença foram registradas perdas na produtividade de $19,2 \%$ (10). O patógeno pode estar associado às sementes, superficialmente, ou causando infecção no seu interior (7). A doença, muito comum em áreas tropicais e subtropicais do mundo (17), pode ocorrer durante todo o ciclo da cultura, desde a fase de plântula até a frutificação (10). Os danos aparecem em forma de lesões nos cotilédones e tombamento de plântulas, lesões nas folhas, formação de cancros no caule e nas hastes (6) e apodrecimento de frutos (11). Em estágios mais avançados é possível observar pequenas pontuações escuras e circulares que correspondem aos picnídios do patógeno, juntamente com exsudado gomoso associado às lesões (5).

Temperaturas entre 20 e $30{ }^{\circ} \mathrm{C}$, com um valor ótimo em torno de $25{ }^{\circ} \mathrm{C}$ e umidade relativa do ar em torno de $95 \%$ são favoráveis ao desenvolvimento do fungo no hospedeiro. O patógeno pode infectar a planta em locais onde a umidade relativa do ar seja inferior a $40 \%$ durante o dia e haja molhamento foliar à noite $(10)$. D. bryoniae pode 
sobreviver nos restos culturais de cucurbitáceas ou em outras plantas hospedeiras (5). Para o controle recomenda-se a adoção de técnicas de manejo integrado, incluindo práticas culturais, controle químico e controle genético com a utilização de genótipos tolerantes e/ou resistentes dentre outras medidas (14). A umidade acompanhada de injúrias no caule (2) e outros ferimentos causados por insetos $(1,8,18)$ podem ser locais de entrada comuns para o patógeno e está entre os fatores mais importantes para a ocorrência da doença (5). Considerandose a suscetibilidade das plantas à doença e a constante presença de insetos-pragas que provocam ferimentos, faz-se necessário lançar mão de diferentes estratégias de manejo, para um sistema de produção eficiente $(3,13)$.

Embora seja de grande importância, para a cultura do meloeiro, o crestamento gomoso do caule tem sido pouco estudado, com reduzido número de trabalhos publicados. O presente trabalho teve como objetivo avaliar a eficácia da aplicação de fungicidas associados a inseticidas no controle do crestamento gomoso do caule e produtividade do meloeiro.

\section{MATERIAL E MÉTODOS}

Foram conduzidos dois ensaios em mesma época, durante a estação seca, no período entre junho a setembro de 2013, em áreas distintas localizadas no Setor de Fitossanidade da Universidade Federal do Tocantins - UFT, município de Gurupi, Estado do Tocantins, Brasil. Estas áreas distanciadas em aproximadamente $300 \mathrm{~m}$ estão inseridas no Bioma Cerrado nas coordenadas geográficas: latitude de 1144'44.866"S e longitude de 49³'8.968'O e altitude de $278 \mathrm{~m}$, possuindo histórico de plantio de meloeiro e infestação natural de crestamento gomoso do caule. O solo é classificado como Latossolo Vermelho-Amarelo distrófico (15) e textura média. Segundo a classificação de Köppen, o clima da região é Aw, definido como tropical quente e úmido com estação chuvosa no verão e seca no inverno. A temperatura média anual está em torno de $26{ }^{\circ} \mathrm{C}$, sendo a amplitude térmica média anual muito pequena, com temperatura média mensal mínima de $20^{\circ} \mathrm{C}$ e média mensal máxima de $33^{\circ} \mathrm{C}$. A precipitação média anual é de $1.632 \mathrm{~mm}$, registrando-se nos meses de outubro a março os maiores índices pluviométricos e, de abril a setembro, os menores (9).

\section{Preparo do solo e plantio das mudas}

O preparo inicial do solo foi realizado de acordo com os costumes locais para a cultura do melão, por meio de duas gradagens pesadas e uma gradagem niveladora, enquanto que, para o levantamento dos canteiros, foi utilizada uma enxada rotativa encanteiradora $(0,70 \mathrm{~m}$ de largura na base superior, $0,90 \mathrm{~m}$ de largura na base inferior e altura de $0,30 \mathrm{~m})$. Os canteiros foram protegidos com lona plástica dupla face (preta/branca) com espessura de 150 micrômetros, deixando-se exposta a face branca. A adubação de base foi feita utilizando-se $1000 \mathrm{~kg} / \mathrm{ha}$ da formulação (N-P-K) 05-25-15, com incorporação de dois litros de esterco bovino curtido de curral por cova. Foi utilizada irrigação localizada por gotejamento com turno de rega fixo e lâmina de irrigação fixa (2,6 L/hora).

A semeadura foi feita em copos descartáveis e o desbaste das plântulas realizado 10 dias após a germinação. Posteriormente, foram transplantadas para 10 covas por parcela, sendo duas plântulas por cova, resultando em um total de 20 plantas por parcela.

Foram utilizadas cultivares distintas em cada ensaio. No primeiro ensaio foi utilizada a Eldorado 300 pois é encontrada facilmente no mercado regional, enquanto no segundo ensaio utilizou-se a Hibrix, por tratar-se de um material que vem apresentando bom rendimento nessas condições edafoclimáticas.

\section{Ensaio I}

Neste experimento com a cultivar Eldorado 300, o delineamento experimental utilizado foi blocos casualizados, com quatro repetições e oito tratamentos. Os tratamentos foram: T1 = testemunha, com aplicação apenas de água nas folhas; T2 = inseticida seletivo (imidacloprido) $300 \mathrm{~g} / \mathrm{ha}$; T3 = inseticida não seletivo (deltametrina) $3 \mathrm{~mL} / 10 \mathrm{~L} \mathrm{de}$ água; T4 = fungicida (tiofanato metilico e clorotalonil) $200 \mathrm{~g} \mathrm{pc} / 100 \mathrm{~L}$ água; T5 = inseticida seletivo (imidacloprido) + fungicida (tiofanato metílico e clorotalonil) + monitoramento de pragas e doenças; T6 = inseticida não seletivo (deltametrina) + fungicida (tiofanato metilico e clorotalonil) + monitoramento de pragas e doenças; $\mathrm{T} 7$ = inseticida seletivo (imidacloprido) + fungicida (tiofanato metílico e clorotalonil); T8 = inseticida não seletivo (deltametrina) + fungicida (tiofanato metilico e clorotalonil). O monitoramento das pragas foi realizado a cada três dias, de acordo com a metodologia preconizada por Sobrinho et al. (18). Para os demais tratamentos, as aplicações foram realizadas a cada sete dias. Os tratamentos foram aplicados, via foliar, ao final da tarde, utilizando-se pulverizador costal a $\mathrm{CO}_{2}$, com bico cônico e pressão constante ajustada para 4,84 libras/pol ${ }^{2}$ e volume de calda ajustado para 200 l/ha.

\section{Ensaio II}

Neste ensaio foi utilizado o hibrido Hibrix, e foram adotados os mesmos tratamentos descritos para o Ensaio I. Contudo, devido ao ataque de animais silvestres (emas e capivaras) na área experimental durante a condução deste ensaio, as parcelas que continham os tratamentos seis a oito, foram destruídas. Portanto serão considerados para este ensaio, apenas os cinco primeiros tratamentos já apresentados no primeiro ensaio. O delineamento experimental, preparo do solo, semeadura, adubação de base, irrigação e aplicação dos tratamentos seguiram a mesma metodologia descrita no Ensaio I.

\section{Avaliação da incidência do crestamento gomoso do caule}

Para avaliar a incidência do crestamento gomoso, as plantas foram monitoradas a cada cinco dias e contabilizado a incidência de plantas com os sintomas da doença de acordo a metodologia utilizada por Santos et al. (13). O número de avaliações de cada ensaio foi de acordo com o início do surgimento da doença. Ao final das avaliações, aos 80 Dias Após o Plantio (DAP) os dados de incidência foram convertidos em Área Abaixo da Curva de Progresso da Doença (AACPD), conforme método descrito por Shaner e Finney (16).

Ao término da última avaliação dos sintomas, fragmentos de caule foram colocados em meio BDA para isolamento do patógeno. Posteriormente os isolados obtidos foram inoculados em plantas sadias das mesmas cultivares de que foram isolados e avaliados os sintomas no intuito de confirmar os postulados de Koch.

Para avaliar a produtividade, todos os frutos comerciais (maduros e com massa superior a $0,5 \mathrm{~kg}$ ) foram colhidos e pesados com balança digital (20 kg x $5 \mathrm{~g})$. Diferenças significativas entre os valores foram determinados usando ANOVA pelo teste de Duncan $(p<0,01$ e $p<0,05)$. A análise estatística foi realizada através do programa Assistat 7.7 e os gráficos produzidos usando Sigma Plot 11.0.

\section{RESULTADOS E DISCUSSÃO}

\section{Ensaio I}

Os resultados observados para a AACPD mostram que nos tratamentos onde foram aplicados apenas inseticidas (T2 e T3), houve 
um maior número de plantas com a presença do crestamento gomoso no caule, apresentando valores superiores a 120 (Figura 1). O tratamento com maior controle da doença foi o T4 com a utilização apenas de fungicida, seguido dos tratamentos com mistura de fungicida com inseticida aplicados semanalmente (T7 e T8).

Em todos os tratamentos foi verificada a presença de insetos praga: Diabrotica speciosa (Germar, 1824) (vaquinha), Diaphania nitidalis (Cramer, 1782) (broca do fruto), Bemisia tabaci (Gennadius, 1889) biótipo B (mosca branca) e Liriomyza trifolii (Burgess, 1880) (moscaminadora). Como nos tratamentos T5 e T6 (monitoramento de pragas e doenças) foi observado nível de dano econômico para insetos praga (D. nitidalis e B. tabaci) apenas duas semanas antes da colheita dos frutos, não foram realizadas aplicações da mistura inseticida + fungicida. Tal fato justifica a alta incidência de $D$. bryoniae nas parcelas destes tratamentos.

Resultados semelhantes foram observados em um trabalho realizado por Santos et al. (12) demonstrando a eficiência no controle da doença com o uso apenas de fungicidas. Em outro trabalho realizado por Santos et al. (10), foi verificado que a mistura de Tiofanato Metílico e Clorothalonil foi eficaz na diminuição do progresso da doença no campo.

Na Figura 2, pode-se observar o progresso do crestamento gomoso do caule do meloeiro nos diferentes tratamentos durante o ciclo da cultura.

Para todos os tratamentos os sintomas da doença iniciaram-se aos 19 DAP. Observou-se um maior progresso da doença nos tratamentos (T1, T2, T3, T5 e T6), a partir dos 44 DAP. Para os demais tratamentos (T4, T7 e T8) o progresso se manteve estável até a colheita. Estes resultados corroboram com Santos et al. (12) que demonstram a eficiência da mistura de tiofanato metílico + clorotalonil, para o controle do crestamento gomoso do caule, na cultura da melancia.

Em relação à produtividade, pode-se verificar que os tratamentos com aplicação semanal de tiofanato metilico + clorotalonil (T4) e a mistura do inseticida deltametrina com os fungicidas tiofanato metilico + clorotalonil apresentaram maior nível de produtividade e diferiram do tratamento com aplicação semanal do inseticida seletivo imidacloprido.

Com relação aos demais tratamentos apesar de ter havido diferença nas parcelas colhidas, não houve significância entre os tratamentos.

\section{Ensaio II}

Os valores observados para a AACPD no ensaio II seguiram a mesma tendência na incidência observada para cultivar Eldorado 300 (Figura 4), com valores superiores a 80 para os tratamentos com aplicação apenas de inseticidas (T2 e T3). .

Os tratamentos contendo a mistura dos fungicidas tiofanato metílico e clorotalonil (T4 e T5) mostraram menor incidência de plantas doentes, com valores de AACPD entre 40 e abaixo de 80, respectivamente. A redução da doença decorrente de aplicação destes fungicidas com relação à testemunha $(\mathrm{T} 1)$ variou entre $74,2 \%$ para $\mathrm{T} 4$ e $61,3 \%$ para T5. Resultados semelhantes demonstrando a eficácia de fungicidas no controle do crestamento gomoso, foram observados em trabalho conduzido por Santos et al. (12) onde mostra valores semelhantes para a AACPD em cultivo de melancia na região.

Para os tratamentos (T2 e T3) nos quais não utilizou-se fungicida como controle, os sintomas da doença iniciaram com 19 DAP (Figura 5).

A doença progrediu de maneira crescente durante todo o ciclo da cultura com pouca oscilação entre eles, resultando em números de 8 a 12 plantas infectadas por tratamento no final do ciclo. Enquanto que as plantas submetidas aos tratamentos com fungicida (T4 e T5) apresentaram sintomas somente a partir dos 29 DAP, e manteve-se constante até o ponto de colheita, aos 79 DAP. A partir da sétima avaliação (44 DAP) apresentando entre duas a quatro plantas infectadas

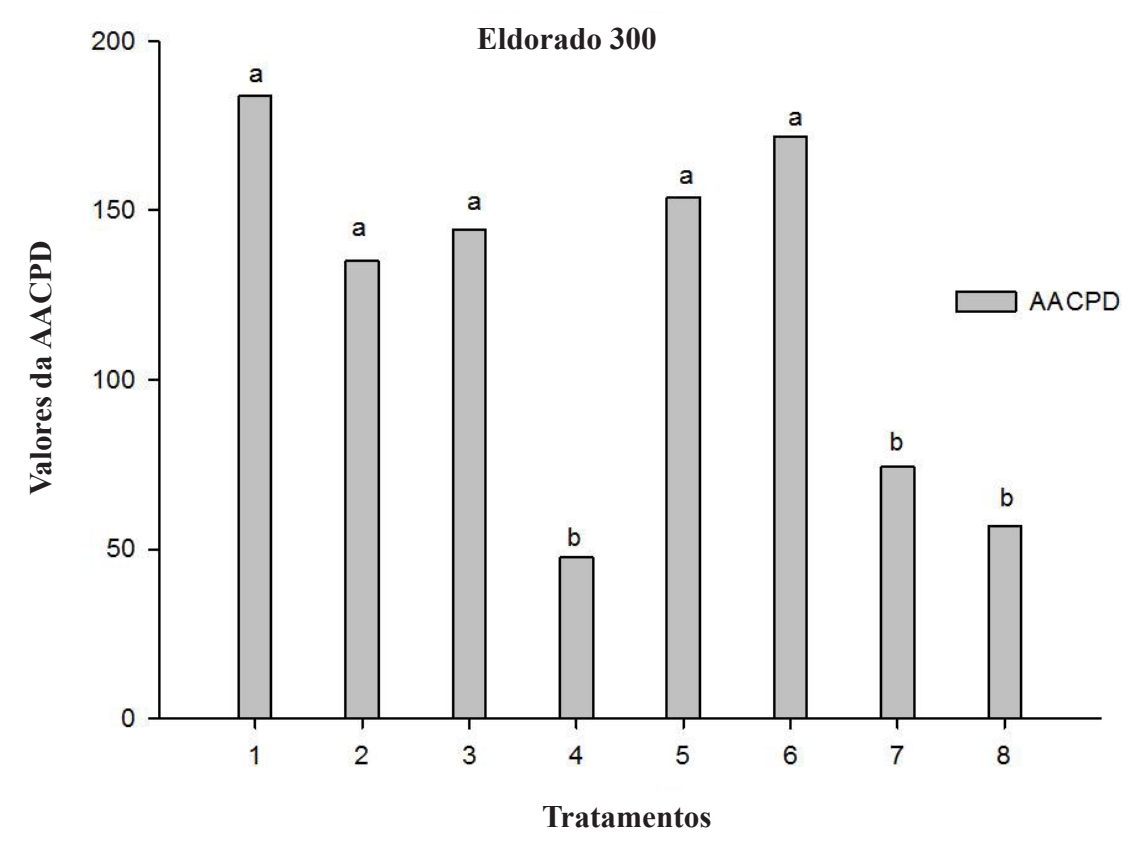

Figura 1. Área Abaixo da Curva de Progresso da Doença (AACPD) do crestamento gomoso do meloeiro submetido a tratamentos com inseticidas e fungicidas, sendo: $(\mathrm{T} 1=$ aplicação de água, testemunha; $\mathrm{T} 2=$ inseticida seletivo (imidacloprido) $300 \mathrm{~g} / \mathrm{ha}$; T3 = inseticida não seletivo (deltametrina) $3 \mathrm{~mL} / 10 \mathrm{~L}$ de água; T4 = fungicida (tiofanato metilico + clorotalonil) $200 \mathrm{~g} \mathrm{pc} / 100 \mathrm{~L}$ água; T5 = inseticida seletivo (imidacloprido) + fungicida (tiofanato metílico e clorotalonil) + monitoramento de pragas e doenças; T6 = inseticida não seletivo (deltametrina) + fungicida (tiofanato metilico e clorotalonil) + monitoramento de pragas e doenças; T7 = inseticida seletivo (imidacloprido) + fungicida (tiofanato metílico e clorotalonil); T8 = inseticida não seletivo (deltametrina) + fungicida (tiofanato metilico e clorotalonil).), no município de Gurupi, Tocantins, 2013. Médias seguidas da mesma letra nas colunas não diferem entre si, de acordo com o teste de Duncan a 1\% de probabilidade; $\mathrm{CV}=33,5 \%$. 


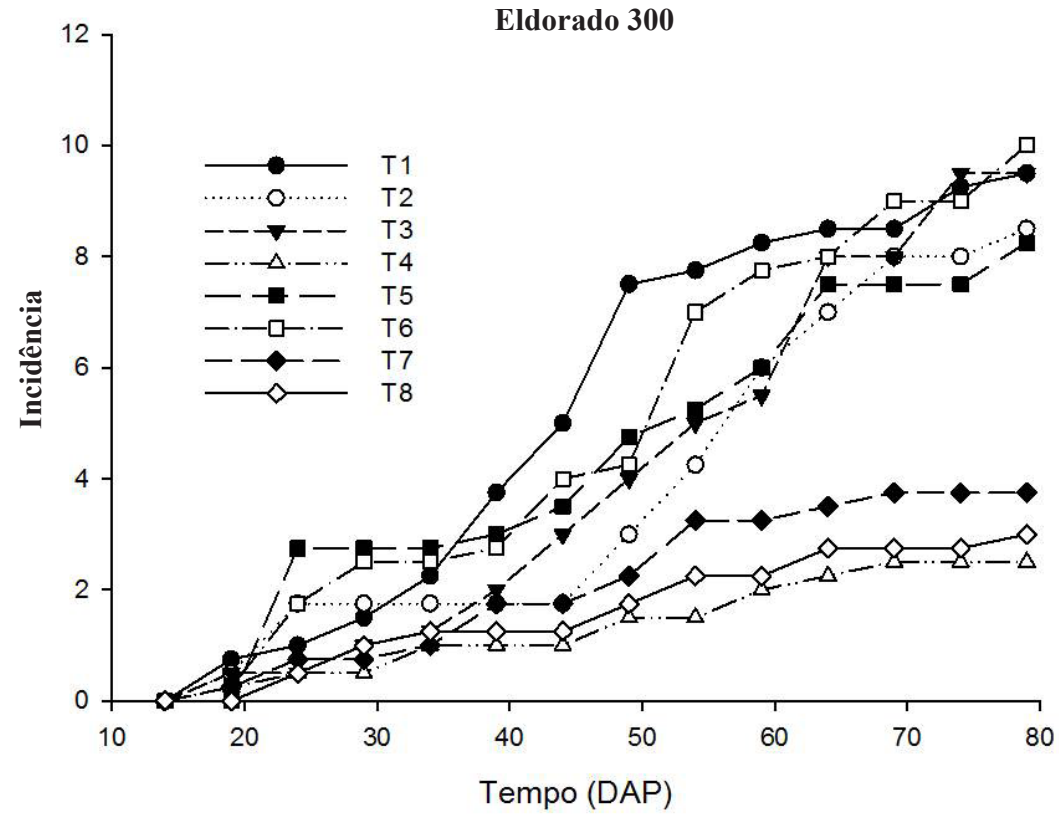

Figura 2. Progresso temporal do crestamento gomoso do caule do meloeiro, submetido a diferentes tratamentos com inseticidas e fungicidas, sendo: ( T1 = aplicação de água, testemunha; T2 = inseticida seletivo (imidacloprido) $300 \mathrm{~g} / \mathrm{ha}$; T3 = inseticida não seletivo (deltametrina) $3 \mathrm{~mL} / 10 \mathrm{~L}$ de água; T4 = fungicida (tiofanato metilico e clorotalonil) $200 \mathrm{~g} \mathrm{pc} / 100 \mathrm{~L}$ água; T5 = inseticida seletivo (imidacloprido) + fungicida (tiofanato metílico e clorotalonil) + monitoramento de pragas e doenças; T6 = inseticida não seletivo (deltametrina) + fungicida (tiofanato metilico e clorotalonil) + monitoramento de pragas e doenças; T7 = inseticida seletivo (imidacloprido) + fungicida (tiofanato metílico e clorotalonil); T8 = inseticida não seletivo (deltametrina) + fungicida (tiofanato metilico e clorotalonil). DAP = Dias Após o Plantio

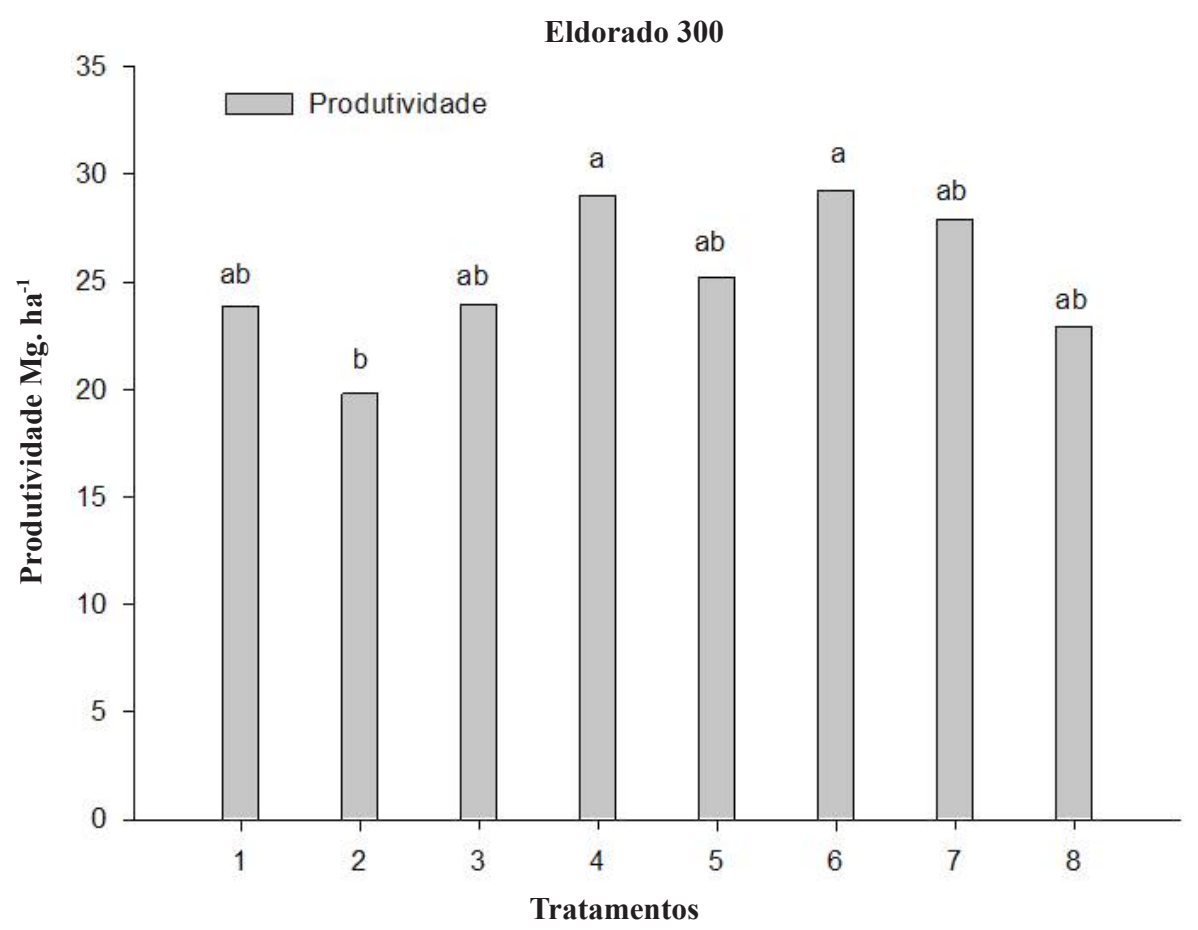

Figura 3. Produtividade de melão, cv. Eldorado 300, submetido a tratamentos com fungicidas e inseticidas para o controle do crestamento gomoso do caule do meloeiro, sendo: (T1 = aplicação de água, testemunha; T2 = inseticida seletivo (imidacloprido) 300g/ha; T3 = inseticida não seletivo (deltametrina) $3 \mathrm{~mL} / 10 \mathrm{~L}$ de água; T4 = fungicida (tiofanato metilico e clorotalonil) $200 \mathrm{~g} \mathrm{pc} / 1001$ água; T5 = inseticida seletivo (imidacloprido) + fungicida (tiofanato metilico e clorotalonil) + monitoramento de pragas e doenças; T6 = inseticida não seletivo (deltametrina) + fungicida (tiofanato metilico e clorotalonil) + monitoramento de pragas e doenças; T7 = inseticida seletivo (imidacloprido) + fungicida (tiofanato metilico e clorotalonil); T8 = inseticida não seletivo (deltametrina) + fungicida (tiofanato metilico e clorotalonil). Médias seguidas da mesma letra nas colunas não diferem entre si, de acordo com o teste de Duncan a $5 \%$; CV $=21,3 \%$. 


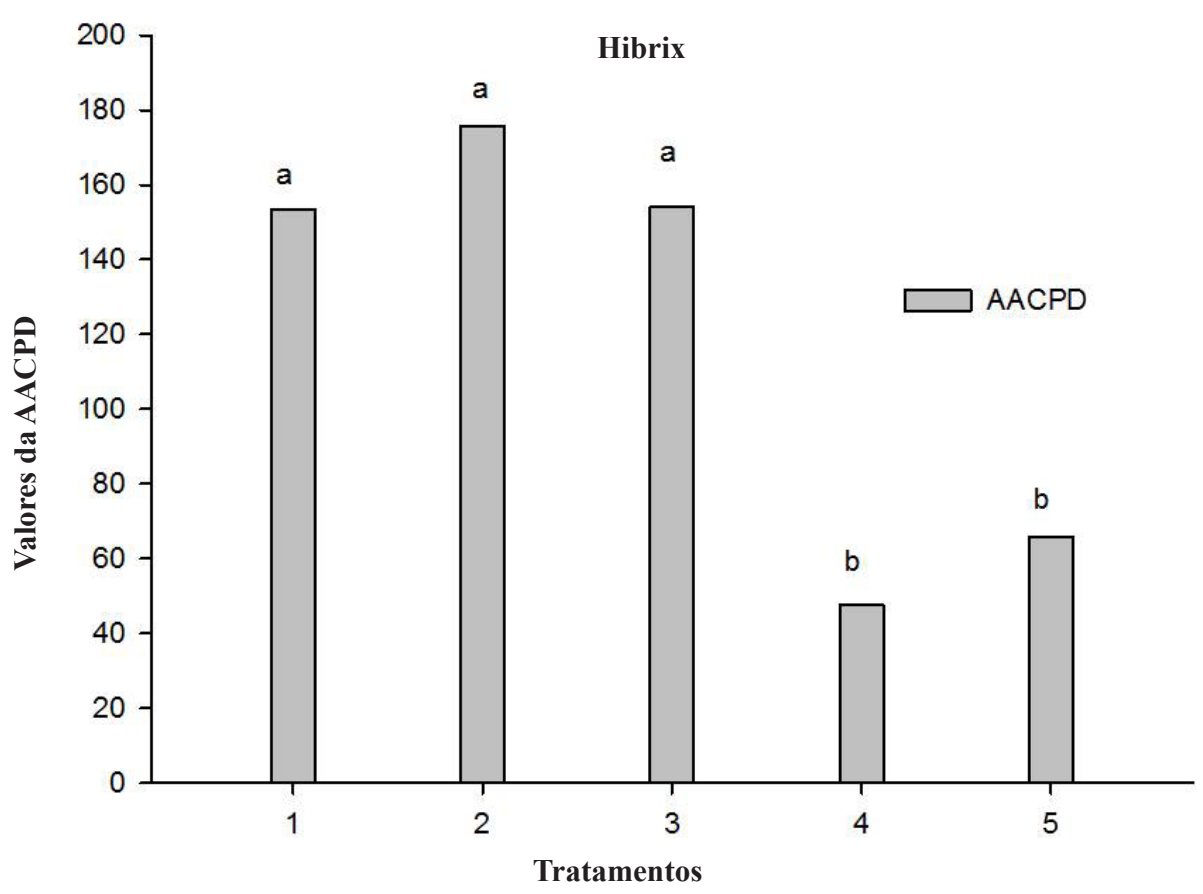

Figura 4. Área Abaixo da Curva de Progresso da Doença (AACPD) do cres

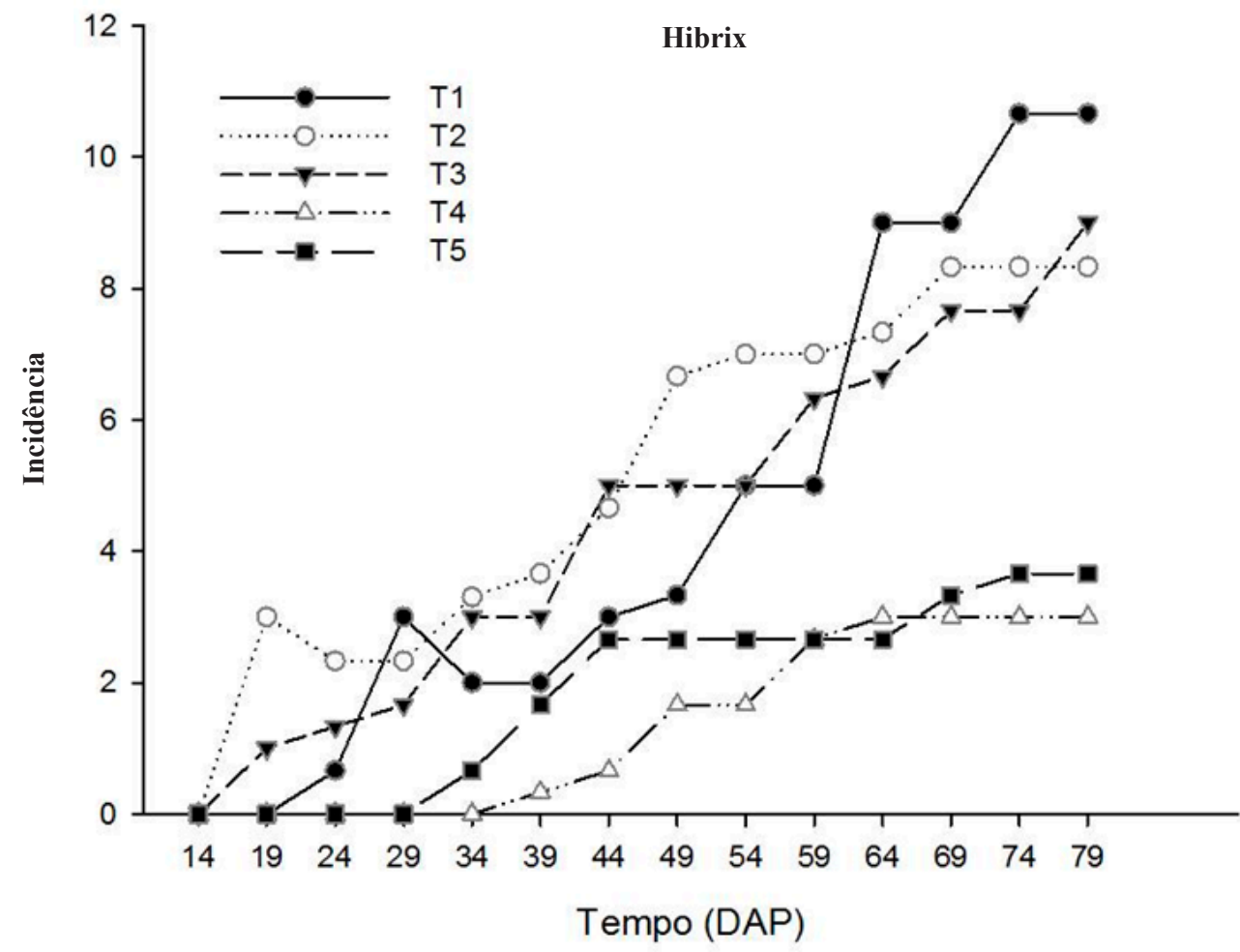

Figura 5. Progresso temporal do crestamento gomoso do caule do meloeiro em função de diferentes tratamentos, sendo: $(\mathrm{T} 1=$ aplicação de água, testemunha; T2 = inseticida seletivo (imidacloprido) 300g/ha; T3 = inseticida não seletivo (deltametrina) $3 \mathrm{ml} / 101 \mathrm{de}$ água; T4 = fungicida (tiofanatometilico e clorotalonil) $200 \mathrm{~g} \mathrm{pc} / 100 \mathrm{~L}$ água; T5 = inseticida seletivo (imidacloprido) + fungicida (tiofanatometilico e clorotalonil) + monitoramento de pragas e doenças; DAP = Dias Após o Plantio

para os dois tratamentos.

Com relação à produtividade dos frutos verificou-se que houve diferença significativa entre os tratamentos testemunha (T1) e inseticida imidacloprido (T2) que apresentaram menor nível de produtividade quando comparados aos demais tratamentos (T3, T4 e T5) (Figura 6).
Pode-se concluir que nos tratamentos onde não houve aplicação de fungicida, a doença foi mais severa, atingindo níveis elevados de incidência, e que o uso de tiofanato metílico mais clorotalonil, foi eficaz no controle do crestamento gomoso do caule das cultivares de melão quando aplicados semanalmente, sendo que o controle de insetos 


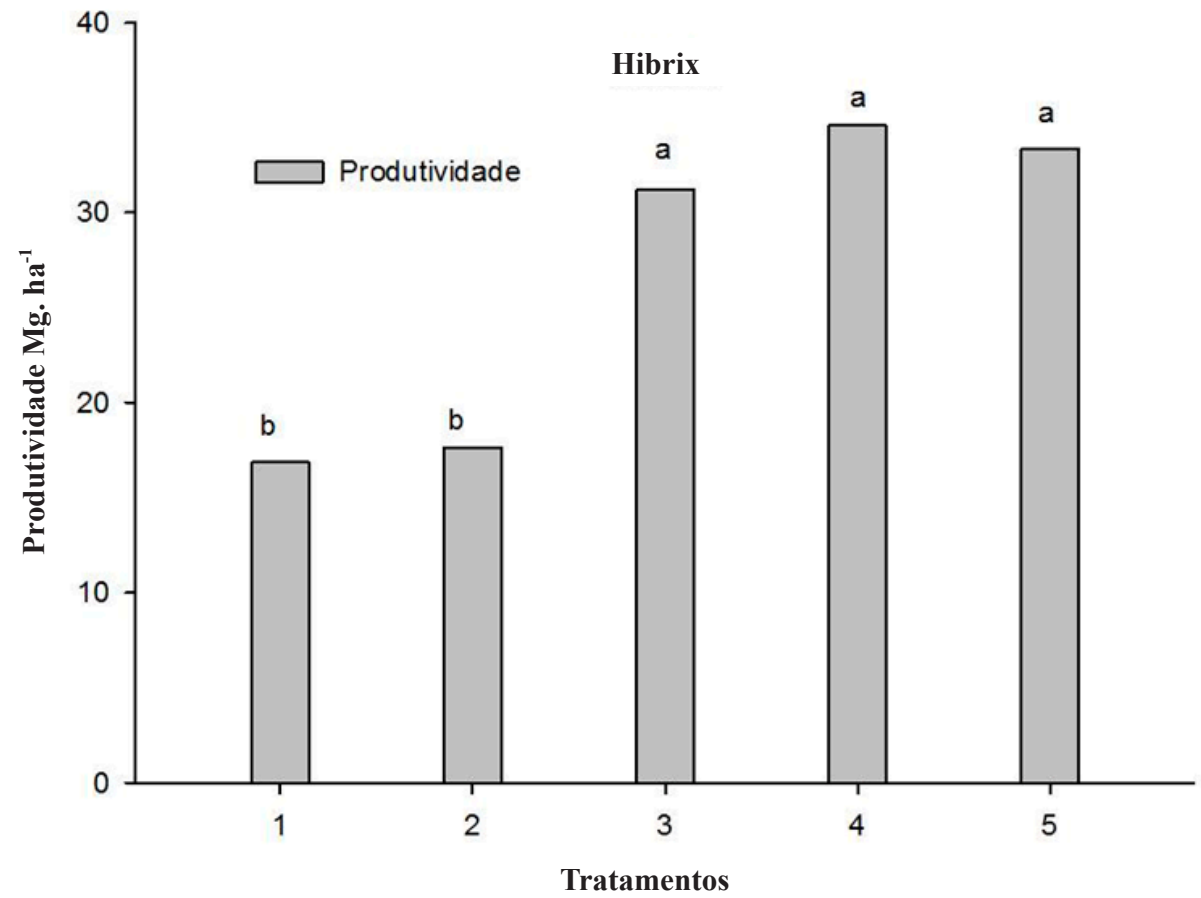

Figura 6. Produtividade de melão, cv. Hibrix, submetido a tratamentos com fungicidas e inseticidas para o controle do crestamento gomoso do caule do meloeiro, sendo: (T1 = aplicação de água, testemunha; T2 = inseticida seletivo (imidacloprido) $300 \mathrm{~g} / \mathrm{ha}$; T3 = inseticida não seletivo (deltametrina) $3 \mathrm{~mL} / 10 \mathrm{~L}$ de água; T4 = fungicida (tiofanatometilico e clorotalonil) $200 \mathrm{~g}$ pc/100 L água; T5 = inseticida seletivo (imidacloprido) + fungicida (tiofanatometilico e clorotalonil) + monitoramento de pragas e doenças. Médias seguidas da mesma letra nas colunas não diferem entre si, de acordo com o teste de Duncan a $5 \%$ de probabilidade; $C V=10,4 \%$

e utilização de inseticidas não influenciaram no controle da doença. Também verificou-se de um modo geral que houve maior produtividade nos tratamentos com aplicações de fungicidas e menores níveis de doença no caule.

\section{AGRADECIMENTOS}

Ao apoio financeiro da Coordenação de Aperfeiçoamento de Pessoal de Nível Superior (CAPES) e Secretaria de Desenvolvimento Econômico, Ciência, Tecnologia e Inovação do Tocantins.

\section{REFERÊNCIAS BIBLIOGRÁFICAS}

1. Babadoost, M.; Zitter, T.A. Fruit roots of pumpkin. A serious threat to the pumpkin industry. Plant Disease, Illinois, v.8, n.93, p.772-782, 2009.

2. Bergstrom, G.C; Knavel D.E.; Kuc, J. Role of insect injury and powdery mildew in the epidemiology of the gummy stem blight disease of cucurbits. Plant Disease, Lexington, v.66, n.8, p.683-686, 1982.

3. Frank, D. L. and O. E. Liburd. Effects of living and synthetic mulch on the population dynamics of whiteflies and aphids, their associated natural enemies, and insect-transmitted plant diseases in zucchini. Environmental Entomology, Maryland, v. 34, n.4, p. 857-865, 2005.

4. IBGE (2015, 08/10/2015). Produção agrícola municipal: quantidade produzida, valor da produção, área plantada e área colhida da lavoura temporária. Disponível em <http//www.ibge.com.br/sidra > . Acesso em: 08 out. 2015

5. Keinath, A.P. Differential susceptibility of nine cucurbit species to the foliar blight and crown canker phases of gummy stem blight. Plant Disease, Charleston, v.98, n.2, p. 247-254, 2014.

6. Kurozawa,C.; Pavan, M.A.; Rezende, J.A.M. Doenças das cucurbitáceas In:Kimati, H.; Amorim, L.; Rezende, J.A.M.; Bergamin Filho, A.; Camargo, L.E.A. Manual de Fitopatologia: Doenças das Plantas Cultivadas. São Paulo: Ed. Agronômica Ceres, 2005. p. 293-310.

7. Lee, H.; Mathur, S.B.; Neergaard, P. Detection and location of seed-borne inoculum of Didymella bryoniae and its transmission in seedlings of cucumber and pumpkin. Phytopathologische Zeitschrift, Berlin, v.109, n.4, p.301-
308, 1984.

8. Palumbo, J. C., N. C. Toscano, M. J. Blua, and H. A. Yoshida. Impact of Bemisia whitefies (Homoptera: Aleyrodidae) on alfalfa growth, forage yield, and quality. Journal of Economic Entomology, Washington, DC, v. 93, n.6, p.1688-1694, 2000.

9. Samani, Z. A.; Hargreaves, G. H. A crop water evaluation manual for Brazil. Logan, Utah State University, 1985.

10. Santos, G.R.; Café-Filho, A.C.; Leão, F.F.; César, M.; Fernandes, L.E. Progresso do crestamento gomoso e perdas na cultura da melancia. Horticultura Brasileira, Brasília, v.23, n.2, p.228-232, 2005.

11. Santos, G.R.; Café-Filho, A.C. Ocorrência do crestamento gomoso do caule em melancia no Tocantins causado por Didymella bryoniae. Fitopatologia Brasileira, Brasília, v. 2, n. 31, p. 208-208, 2006.

12. Santos, G.R.; Café-Filho, A.C.; Saboya, L.M.F. Controle químico do crestamento gomoso do caule na cultura da melancia. Fitopatologia Brasileira, Brasília, v. 30, n. 2, p.155-163. 2005.

13. Santos, G.R.; Leão, E.U.; Castro, H.G.; Nascimento, I.R.; Sarmento, R.A.; Sarmento-Brum, R.B.C. Crestamento gomoso do caule da melancia: Etiologia, epidemiologia e medidas de controle. Journal of Biotechnology and Biodiversity, Gurupi, v. 2, n. 2, p. 52-58, 2011.

14. Santos G.R.; Zambolim L.; Resende J.A.M.; Costa H. Manejo Integrado de Doenças da Melancia. Viçosa: Ed. UFV, 2005. 70 p.

15. Santos, H. G.; Almeida, J.; Oliveira, J. D.; Lumbreras, J.; Anjos, L. D.; Coelho, M.; Jacomine, P.; Cunha, T. D. ; Oliveira, V. D. Sistema brasileiro de classificação de solos. Brasília, Embrapa. 2013.

16. Shaner, G.; Finney, R.E. The effect of nitrogen fertilization on the expression of slow - mildewing resistance in Knox Wheat. Phytopathology, St. Paul, v.67, n.8, p. 1051-1056, 1977.

17. Sitterly, R.W; Keinath, A.P. Gummy Stem Blight. In: Zitter, T; Hopkins, D; Thomas, C. Compendium of Cucurbit Diseases. APS Press, St. Paul, 1996. p.27-28.

18. Sobrinho, R.B.; Guimarães, J.A.; Araújo, E.L.; Moreira, M.A.B.; Mesquita, A.L.M. Manejo integrado de pragas do meloeiro. Fortaleza: Embrapa Agroindústria Tropical, 2011. Disponível em: http://www.cnpat.embrapa.br/ download publicacao.php?id=333. Acesso em: 10 jun. 2014.

19. Vida, J.B.; Souto, E.R.; Nunes,W.M.C. Perdas causadas por Mycosphaerella melonis na cultura do melão em estufas plásticas. Fitopatologia Brasileira, Supl., Brasília, v.18, p.324, 1993 (Resumo). 